\section{De lokale leiderschapstandem: \\ een verkennend onderzoek naar de aard en \\ hoedanigheid van het politiek en ambtelijk \\ leiderschap in Vlaamse stadsbesturen}

Nathalie VALLET

Docent aan het Departement Management van de Universiteit Antwerpen en aan de Master in Publiek Management van de Universiteit Antwerpen Management School (UAMS)

Filip DE RYNCK

Hoogleraar aan het Departement Handelswetenschappen en Bestuurskunde van de Hogeschool Gent en docent aan de Master in Publiek Management van de Universiteit Antwerpen Management School (UAMS)

\section{Inleiding}

Het politiek en ambtelijk leiderschap zoals dit momenteel in de 13 Vlaamse centrumsteden wordt waargenomen door de leden van het college van burgemeester en schepenen (CBS) en het managementteam (de stadssecretaris, de stadsontvanger en de directeurs of afdelingshoofden) vormt het centrale aandachtspunt van ger en de directeurs of afdelingshoofden) vormt het centrale aandachtspunt van
dit artikel. Aangezien ze samen het leiderschap binnen de respectievelijke stadsbesturen waarnemen, spreken we over de zogenaamde lokale leiderschapstan$\mathrm{dem}$. De tandem metafoor benadrukt de tweeledigheid en de hiermee samenhangende interacties: het politiek en ambtelijk leiderschap kunnen elkaar ondersteunen en versterken, mar ze kunnen elkar evenzeer tegenwerken en verzwakken. sprint voorwaarts, in het tweede geval een weinig constructief getrappel ter plaatse. De lokale leiderschapstandem heeft belangrijke gevolgen voor de integrale werking van het stadsbestuur. Een vlotte sprint voorwaarts impliceert een sterk draagvlak voor het toekomstige beleid. Een weinig constructief getrappel ter plaatse impliceert een stroeve en onduidelijke aansturing.

De centrale onderzoeksvraag die in dit artikel zal beantwoord worden, luidt: hoe ziet de lokale leiderschapstandem er precies uit? Wat weten we over het politiek

446 | Res Publica $\vee 2006 / 4$ en ambtelijk leiderschap zoals het momenteel wordt ingevuld in de Vlaamse centrumsteden? Wat zijn de typische kenmerken en waardoor worden ze beïnvloed? Het antwoord op deze vragen wordt afgeleid uit een recent gerealiseerd onderzoeksproject. ${ }^{1}$ Het onderzoek heeft niet tot doel gehad om de leiderschapstandem als zodanig in kaart te brengen. Maar, de verzamelde data verstrekken ons wel bruikbare informatie.

De structuur van het artikel ziet er uit als volgt. In een eerste deel staan we stil bij het theoretische referentiekader. Na een korte conceptuele duiding, komen de onderzoekstradities omtrent het politiek en ambtelijk leiderschap aan bod. In een daaropvolgend, tweede deel bespreken we het onderzoeksontwerp. In een derde en tevens laatste deel staan de concrete onderzoeksresultaten centraal.

\section{Het theoretische referentiekader}

\section{A. Het dubbelzinnige concept leiderschap}

Een belangrijke vraag die zich stelt, luidt: wat verstaan we precies onder politiek en ambtelijk leiderschap? Het antwoord op deze vraag is conceptueel gezien niet eenvoudig. Het begrip leiderschap is immers een vaag, zeer breed en moeilijk af te bakenen concept. Bovendien zit de literatuur over politiek en ambtelijk leiderschap verspreid over diverse (deel)vakgebieden, ${ }^{2}$ iets wat de conceptuele helderheid alvast niet ten goede komt.

Volgens de managementliteratuur die het concept in zijn meest algemene betekenis duidt, heeft leiderschap te maken met de aansturing binnen organisaties. ${ }^{3}$ Aansturen impliceert het initiëren, activeren, faciliteren en ondersteunen van beleidsprocessen alsook van de hierbij betrokken medewerkers in de richting van vooropgestelde doelrealisaties. Leiding geven heeft daardoor een uitgesproken

1. Concreet gaat het om het "Stadsmonitor project voor Leefbare en Duurzame Vlaamse steden", een project van de Vlaamse Gemeenschap (Stedenbeleid), zie ook II. A.

O.a. COLE, A. Studying Political Leadership: the case of Francois Mitterand, Political Studies, XLII, 2001, pp. 453-468.

Pp. heeft betrekking op de door de organisatie nagestreefde doelen en dus de intes. Plannen procesmatige vormgeving van de beleidsprocessen. Organiseren heeft betrekking op het organisatiestructurele raamwerk waarbinnen de plannen en beleidsprocessen plaats grijpen. Leiding geven heeft eerder betrekking op het activeren van alle organisatieleden binnen dit raamwerk in de richting van de vooropgezette doelen. En controleren slaat op het navolgen, bijsturen en op elkaar afstemmen van beleidsprocessen, organisatiestructuren en leiderschapsstijlen in functie van de beoogde doelrealisatie. Zie o.a. MARTIN, J., Organizational Behaviour, London, Thomson Learning, 2001; HANNAGAN, T., Management, Concepts and Practices, Essex, Pearson Education-Prentice Hall, 2002; BLOISI, W., COOK, C.W., HUNSAKER, P.L., Management and Organizational Behaviour, London, McGraw Hill, 2003. 
doel- en mensgerichte dimensie: mensen worden doelgericht of beleidsmatig aangestuurd. In principe kan iedereen leiding geven, hetzij formeel hetzij informeel, hetzij in zijn algemeenheid hetzij binnen een specifiek beleidsdomein, hetzij met betrekking tot de hele organisatie hetzij met betrekking tot slechts een onderdeel rexpliciet aan welke functies er structureel en formeel verondersteld worden om leiding te geven. Concreet betreft het zogenaamde managementfuncties of beleidsverantwoordelijken. Volledigheidshalve lijkt het vermelden van kritische bedenkingen zinvol. Leiding geven is immers één van de meest dubbelzinnige managementfuncties. Vooral de relatie en het verschil met het meer algemene begrip van manager of management is niet steeds duidelijk. Sommige auteurs beschouwen leiding geven als één

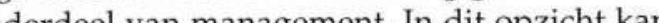
leiding geven interageren met de andere managementfuncties, maar staat het in essentie naast plannen, organiseren en controleren. Anderen beschouwen beide begrippen als synoniemen van elkaar: leiders of beleidsverantwoordelijken zijn managers en vice versa. Leiding geven staat dan niet naast maar omvat het plannen, organiseren en controleren van de organisatie. Dit is wat sommige de meest brede en allesomvattende invulling van het concept leiding geven noemen.

Indien we binnen publieke organisaties - en zo ook stadsbesturen - op zoek gaan naar beleidsverantwoordelijken of leidinggevenden, dan komen we ingevolge het publieke karakter van deze organisaties terecht bij welbepaalde functies binnen zowel het politiek als het ambtelijke apparaat. In dit opzicht is er duidelijk sprake van een "tweehoofdig" leiderschap.

In de politicologische literatuur komt het politiek leiderschap uitgebreid aan bod, zo ook de specifieke invulling ervan op lokaal niveau ${ }^{4}$ Qua conceptuele invulling concluderen divers nities bestaan. Hierdoor wordt het specifieke concept van politiek leiderschap uiterst verwarrend en onduidelijk. ${ }^{5}$ Vooral de associatie met vage en allesomvattende begrippen zoals macht, invloed, autoriteit en controle maken dat leiderschap een weinig grijpbaar en onderzoeksmatig moeilijk meetbaar concept wordt. Cole bevestigt deze onduidelijkheid maar onderneemt alvast een interessante poging om de verschillende accenten of invalshoeken die in de vakliteratuur gebruik (

4. EDINGER, LJ, Approaches to the Comparative Analysis of Political Leadership, Review

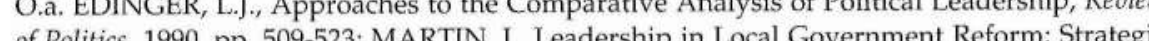
of Politics, 1990, pp. 509-523; MARTIN, ., Leadership in Local Government Reform: Strategic Direction versus administrative Compliance, Australian Journal of Public Administration, $58(2)$, 1999, pp. 24-37; CHRISTENSEN, T., Administrative Reform: Changing Leadership Roles?, ,
ternational Journal of Policy and Administration, 2001, pp. 457-480; LEAH, S., WILSON, D., Rethinking Local political Leadership, Public Administration, 80(4), 2002, pp. 665-689; BORRAZ, O., JOHN, P., The Transformation of Urban Political Leadership in Western Europe, International Journal of Urban and regional Research, 28(1), 2004, pp. 107-120.

5. EDINGER, L.J., o.c., p. 510 .

48 | Res Publica $\nabla 2006 / 4$ een formele functiegebonden controle over politieke instituties), met het vertonen van een welbepaald gedrag (politiek leiderschap als een stijl), met het bestaan van een complexe leider-volger relatie (politiek leiderschap als een organisatiestructurele constructie) en met het stofferen van het politiek discours (politiek leiderschap als een maatschappelijk fenomeen). Al naargelang een ander accent, zullen andere vakgebieden de nodige kennis en inzichten aanreiken om het fenomeen te bestuderen (bv. politicologie, sociologie, managementwetenschappen, ...).

De aandacht voor het ambtelijk leiderschap is beperkter qua omvang, hoewel het indirect wel aan bod komt in de literatuur over politiek-ambtelijke verhoudingen en gelijknamige modellen (zie C). Het ambtelijke leiderschap is dan één aandachtspunt of rol binnen een ruimer pakket aan ambtelijke voorbereidings- en uitvoeringsrollen. ${ }^{6}$

\section{B. De theoretische typering van politiek leiderschap}

Een volgende vraag die zich stelt luidt: hoe ziet het politiek leiderschap er precies uit? Op welke wijze kunnen we het politiek leiderschap typeren en duiden? Welke modellen en/of theorieën bestaan hierover?

In de vakliteratuur bestaan er diverse pogingen om het politiek leiderschap in zijn algemeenheid en het lokaal politiek leiderschap in het bijzonder te typeren. Deze literatuur is echter diffuus in die zin dat ze geen vaste of algemeen aanvaarde typeringen bevat. Mogelijks heeft dit gevarieerde aanbod te maken met de eerder aangehaalde onduidelijke conceptualisering (zie I.A). De vele conceptuele invullingen of accenten impliceren logischerwijze vele typeringen en duidingmogelijkheden.

Interessant in het kader van dit artikel zijn enkele synthese- of integratiepogingen. Sommige auteurs hebben immers geprobeerd om het gevarieerde aanbod onder te brengen in een overzichtelijk en beheersbaar geheel. Zo is er bijvoorbeeld de synthese van Edinger die een tweetal hoofdstromingen en een drietal substromingen onderscheidt. ${ }^{7}$ Volledigheidshalve moeten we opmerken dat deze synthese overwegend betrekking heeft op de Angelsaksische en Amerikaanse vakliteratuur.

6. O.a. ABERBACH, J., PUTNAM R. \& B. ROCKMAN, Bureaucrats and Politicians in Western Democracies, Cambridge, Harvard University Press, 1981; PETERS, G., Politicians and Bureaucrats in the Politics of Policy-making, in: LANE, J., Bureaucracy and Public Choice, Bristol, Sage, Service Bargains Old and New, in. PETERS G. \& I SAVOIE Governabice in the Twents: Public Century, Montreal, McGille-Queen University Press, 2000, pp. 178-209: SVARA, J J The Roles of the City Council and Implications for the Structure of City Government, National Reles of the City Council and Implications for the Structure of City Government, National 7. EDINGER, L.J., o.c., p. 512-513. 
Een eerste hoofdstroming heeft betrekking op de zogenaamde descriptieve theorieën en modellen. In deze theorieën en modellen proberen onderzoekers voora het type of de aard van het politiek leiderschap te karakteriseren aan de hand van gedragsmatige of stijlgebonden trefwoorden. Zelf zijn we geneigd te stellen da deze traditie goed aansluit bij studies of theorieën die gebruik maken van de gedrags- of stijlmatige conceptualisering volgens Cole (zie I.A). De concrete typeringen zijn divers. Zo wordt er veel aandacht besteed aan de sterkte of intensiteit van het leidinggevende gedrag. ${ }^{8}$ Maar, ook de eenheidzoekende versus verdeeldheid bevorderende stijl komt veelvuldig aan bod. Leah en Wilson concluderen bijvoorbeeld dat er heel wat studies bestaan over het cohesie zoekend gedrag van politieke leiders. Concreet impliceert dit gedrag een teamgerichte of geïntegreerde aansturing van het integrale lokale bestuur. ${ }^{9}$ Verder bestaan er ook stijgebonden duidingen die verwijzen naar het karakter van politieke beleidsverantwoordelijken, bijvoorbeeld een autocratische of een vernieuwende stijl, en naar de aandacht di politieke beleidsverantwoordelijken vertonen voor de politieke beleidsarena. In dit laatste geval gaat men op zoek naar de concrete, gedragsmatige implicaties van de politieke vertegenwoordigingsrol. ${ }^{10}$

Een tweede hoofdstroming is gebaseerd op de zogenaamde analytische traditie. Nast beschrijvingen Naast beschrijvingen staan vooral achterliggende of verklarende factoren centraal. Doorgaans kunnen er drie substromingen worden onderscheiden. ${ }^{11}$ Een eer-
ste substroming besteedt veel aandacht aan de contextuele factoren zoals de organisatiestructuur en de onderliggende culturele patronen. Hierbinnen situeert zich de institutionele theorievorming waarbij het accent komt te liggen op de invloed van het formeel wettelijk kader. Concreet betreft het bijvoorbeeld studies waarin de impact van rechtstreeks verkozen burgemeesters op het vertoonde politiek leiderschap centraal staan. Zelf zijn we geneigd te stellen dat deze traditie goed aansluit bij studies of theorieën die gebruik maken van de institutionele conceptualisering van Cole (zie I.A). Oordelend op basis van het grote aanbod aan publicaties over het rechtstreeks verkozen burgemeesterschap zijn we geneigd te stellen dat deze stroming momenteel sterk vertegenwoordigd wordt. ${ }^{12}$ Een twee-

8. O.a. HAMBLETON, R., Strengthening Political leadership in UK Local Government, Public Money \& Management, January-march, 1998, pp. 41-51; BORRAZ, O., JOHN, P., o.c., p. 107 108.

9. Leah en Wilson baseren hun bevindingen op diverse publicaties waaronder deze van Selznick (1957), Jones en Norton (1977), Game (1979), John en Cole (1999), Elcock (2001) en Kotter en Lawrence (1974). Zie LEAH, S., WILSON, D., o.c., p. 667-669.

10. Volgens hetzelfde literatuuroverzicht van Leah en Wilson wordt er via het zogenaamde veregenwoordigingsgedrag van politieke beleidsverantwoordelijken indirect veel aandacht b LEAH, S., WILSON,D., o.c., p. $667-669$.

12. O.a. HAMBLETON, R., o.c., pp. 42-43; BORRAZ, O., JOHN, P., o.c., p. 107-120; FENWICK, J. ELCOCK, H. New devent the elected Mayor and local leadership, Public Money \& Management, January, 2005, p. 61-66; REYNAERT, H., STEYVERS, K., DELWIT, P., PILET J.B.. Revolution or renovation? Reforming Local Politics in Europe, Brugge, Van Den Broele, 2005.

| 50 Res Publica $₹ 2006 / 4$ de substroming legt accenten op persoonsgebonden attributen en vaardigheden zoals bijvoorbeeld vaardigheden op het gebied van communicatie, netwerkvorming, visievorming, creativiteit en conflicthantering. ${ }^{13}$ De aanwezigheid ervan heeft een aanzienlijke invloed op het vertoonde politiek leiderschap. Deze sub stroming is binnen de vakliteratuur eveneens sterk vertegenwoordigd. De theorievorming ter zake resulteert in "rational-choice" modellen en "psychologische actor" modellen. In het eerste geval is het politiek leiderschap het gevolg van een rationele calculus, in het tweede geval van sociaal psychologische overwegingen. Een derde substroming legt accenten op de persoongebonden attibuten of varschappelijke bewegingen, politieke strekkingen of medewerkers. Binnen deze stroming situeren zich de zogenaamde "leider-volger" theorieën waarvan de charismatische leiderschapsrelatie momenteel veel aandacht krijgt.

\section{De theoretische typering van ambtelijk leiderschap}

Doorgaans treffen we veel minder literatuur aan over het ambtelijk leiderschap. In de literatuur komt het ambtelijk leiderschap indirect aan bod bij de bestuurskundige typeringen van de zogenaamde politiek-ambtelijke verhoudingen. Concreet gaat het over modellen waar de rol- en taakverdeling tussen politiek en ambtelijke beleidsverantwoordelijken centraal staan. Bij wijze van voorbeeld gaat het om de oude bureaucratische modellen gebaseerd op het gedachtegoed van Wilson (1887) en Weber, de reflecties hierop van ondermeer Waldo (1948) en Svara (2002), en de meer recente modellen van Hood (2000), Aberbach, Putnam en Rockman (1981), en Peters (1987). ${ }^{14}$

Het is belangrijk om op te merken dat deze modellen in principe betrekking hebben op het integrale rollenpakket van de ambtelijke top en dus niet over het ambtelijk leiderschap alleen. Doorgaans is het ook de lezer zelf die i.v.m. het omschreven rollenpakket moet afleiden wat dit precies kan impliceren voor de aansturingrol. Zo zal bijvoorbeeld de leiderschapsrol in het geval van een klassiek rollenpakket waarbij de bijdrage van ambtelijke beleidsverantwoordelijken doorgaans beperkt is tot de operationele uitvoering van de door de politieke beleidsverantwoordelijken genomen beleidsbeslissingen, mogelijks getypeerd kunnen worden als "intern gericht", "volgend" en "zwak" (zie IV. C.).

13. O.a. HAMBLETON, R., o.c., p. 46-47; BORRAZ, D., JOHN, P., o.c., p. 112-113; MARTIN, J., o.c., p. 32

14. WII SON, W, The Study of Adninit

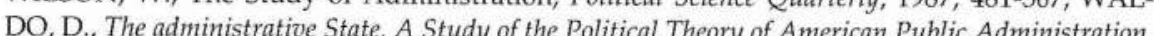
New York, Holmes en Meier, 1948. SVARA JH. o.c. HOOD, Crican Public Administration, NAM R, ROCKMAN, B, OC. PETERS, G, Comparing Public Buresucracies, Tuscaloos, Uni- 
Verder treffen we in sommige publicaties over politiek leiderschap ook enkele ex pliciet afgeleide bedenkingen aan over het ambtelijk leiderschap. Doorgaans betreft het bedenkingen in het kader van institutionele hervormingen die een directe impact hebben op de kracht en intensiteit van het politiek leiderschap. Zo kan er bijvoorbeeld gedacht worden aan het gebruik van mandaatsystemen en de introductie van managementcontracten. De onderzoeksresultaten of bedenkingen zijn echter dubbelzinnig. Sommige menen dat dit de ambtelijke aansturing aanzienlijk versterkt ten nadele van de politiek, terwijl anderen menen dat dit juis een tegenovergesteld effect genereert. ${ }^{15}$ Het ambtelijk leiderschap komt immers in een strakker en vooral risicovoller keurslijf te zitten. Volledigheidshalve kunnen we ons afvragen in hoevere deze publicati nen we ons afvragen in hoeverre deze publicaties eenzel de van het concept ambtelijk leiderschap. Soms hebben we de indruk dat het eerder gaat over ambtelijke rollenpakketten zoals het geval in de hiervoor aangehaalde modellen omtrent politiek-ambtelijke verhoudingen

\section{Het empirische onderzoekskader}

In het nu volgende deel schetsen we vooreerst het onderzoeksproject waarbinnen de data over het politiek en ambtelijk leiderschap werden verzameld. Daarna staan we stil bij de aangewende methodologie.

\section{A. Het onderzoeksproject}

De onderzoeksresultaten zijn afkomstig uit het tweede onderzoeksluik van het Stadsmonitor project voor leefbare en duurzame Vlaams steden (Vlaamse Gemeenschap, Stedenbeleid, 2000-2005) ${ }^{16}$ De centrale probleemstelling luidde: hoe ziet het bestuurskundig en beleidsmatig functioneren van Vlaamse stadsbesturen er momenteel uit, hoe evolueert dit en in hoeverre is dit belangrijk voor het toekomstige gebruik van de stadsmonitor? Het politiek en ambtelijk leiderschap maken, naest hel wat andere kenmerken van stadsbesturen, deel uit van de beleid en bestuurskundige context waarin de stadsmonitor zal terecht komen. In dit opzicht hebben we binnen het onderzoek dan ook heel wat informatie verzamel over het politiek en ambtelijk leiderschap. Gegeven de centrale focus van het arti-

15. CHRISTENSEN, T., o.c., p. 457; SHERGOLD, P., Lackies, Careerists, Political Stooges? Personal reflections on the Current State of Public Service Leadership, Australian Journal of Public Administration, 63(4), 2004, pp. 3-13; POLSBY, N.W., Legitimacy in British Policy-makin Functional Alternatives to Civil Service, British journal of 3(1), 2001, pp. 5-35.

16. Het eerste onderzoeksluik heeft betrekking op de ontwikkeling van de Stadsmonitor, met name een coherente set van 180 omgevingsindicatoren waarmee beleidsverantwoordelijken, kunnen vormen over de leefbaarheid en duurzaamheid van de 13 Vlaamse centrumsteden. Zie: www.thuisindestad.be

452 | Res Publica $\$ 2006 / 4$ kel beperken we ons tot de beschrijving van de onderzoeksresultaten in functie van de lokale leiderschapstandem. We staan dus niet stil bij de eventuele implicaties voor het gebruik van de stadsmonitor.

\section{B. De gehanteerde onderzoeksmethode}

Het onderzoek vertoont een overwegend kwalitatief en inductief ontwikkelingskarakter. Aangezien een dieptezicht op het feitelijk functioneren van stadsbesturen grotendeels ontbrak bij de aanvang van het onderzoek - de meeste publicaties hadden betrekking op gewenste of veronderstelde bestuurskundige en beleidsmatige evoluties, bijvoorbeeld in het kader van NPM en/of governance ${ }^{17}$ was het gebruik van een kwalitatieve, exploratieve onderzoeksmethode aangewezen. Concreet hebben we ons geïnspireerd op de algemene principes van de gefundeerde theoriebenadering. ${ }^{18}$

Zoals gebruikelijk bij kwalitatieve onderzoeksmethoden zijn we niet vertrokken van een ex ante literatuurstudie die resulteert in een strak omlijnd onderzoekskader aan de hand waarvan data op een zeer systematische, gerichte en weldoordachte wijze worden verzameld en geanalyseerd. Het risico bestaat dan immers dat onderzoekers enkel zien wat de theorie zegt dat ze moeten zien, of dat onderzoekers enkel kijken naar datgene waarnaar de theorie zegt dat ze moeten kijken. In dit opzicht hebben we ons bij de inventarisatie van het politiek en ambtelijk leiderschap dan ook niet zozeer laten leiden door theoretische referentiekaders, maar wel door het onderzoeksveld zelf. Dit neemt niet weg dat we onze tussentijdse analyses net zoals de meeste kwalitatieve onderzoekers ex post hebben geconfronteerd met een bruikbaar theoretisch referentiekader - kwestie van een houvast te vinden voor de veelheid aan verzamelde data- en dat we ons nadien ook de vraag hebben gesteld wat we precies hebben bijgeleerd in functie van de reeds bestaande theorie? Hoe verhouden de onderzoeksresultaten zich tot de theoretische modellen en tradities ter zake? In dit opzicht krijgen literatuurstudies binnen kwalitatief onderzoek een beduidend andere functie en betekenis dan binnen - klassiek - kwantitatief en falsifiërend onderzoek.

17. N. VALLET, F. DE RYNCK, Leven van en over stadsorganisaties, Rapport van de bestuurskundige en beleidsmatige context voor het maken van een stadsmonitor, De cases Antwerpen, Mechelen, Leuven en Oostende in synthese, Brussel, Vlaamse Gemeenschap Stedenbeleid, 2005, p. 12-16.

18. O.a. GLASER, B.G., STRAUSS,A.L., The Discovery of Grounded Theory: Strategies for Qualitative Research, New York, Aldine De Gruyter, 1967; STRAUSS, A.L., Qualitative Analysis for Social Qualitative Research, Grounded Theory Procedures and Techniques, London, Sage Publications 1990; MILES, M.B., HUBERMAN, A.M., Qualitative Data Analysis, London, Sage Publications, 1994; WESTER, F., Strategieën voor kwalitatief onderzoek, Bussum, Couthino, 1995; MASO, I. SMALING, A., Kwalitatief onderzoek: praktijk en theorie, Amsterdam, Boom, 1998; TEN HAVE, P., WESTER, F., SMALING, A., De Grounded Theory-benadering in discussie, Tijdschrift voor Kwalitatief Onderzoek in Nederland, 9/3, 2004, pp. 7-17. 
Conform de richtlijnen van de gefundeerde theoriebenadering, bestaat het onderzoek uit 4 longitudinale gevalstudies (duurtijd 2 jaar), aangevuld met een aantal periodieke focusgroep gesprekken waarin de vaststellingen uit de gevalstudies worden afgetoetst bij een ruimere en meer representatieve groep van politieke en wijze wordt er gestreefd naar een meer algemene en representatieve geldigheid van de onderzoeksresultaten. Toegegeven, dit is slechts een initiële poging tot veralgemening die zeker nog verder moet worden afgetoetst.

De 4 longitudinale gevalstudies grepen plaats in de steden Oostende, Mechelen, Leuven en Antwerpen. Ideaaltypisch zouden alle Vlaamse centrumsteden moeten worden opgenomen in het onderzoek, maar praktische beperkingen noodzaken keuzes. De selectie van de vier steden is opnieuw gebaseerd op de methodische richtlijnen ter zake: een rijke inductieve ontwikkeling noodzaakt onderzoek in onderling sterk van elkaar verschillende onderzoekssubjecten. De vier weerhouden stadsbesturen verschillen onderling in omvang, strategisch draagvlak ambtelijke en politieke capaciteiten en stedelijke netwerksturing. ${ }^{19}$ Ex post stellen we bijkomend vast dat ook de invulling en de aard van het politiek en ambtelijk leiderschap sterk varieert. Dit heeft alvast geleid tot een vrij genuanceerde en rijke beeldvorming over de concrete verschijningsvorm van de lokale leiderschapstandem.

Voor de dataverzameling maken we analoog met de methodische richtlijnen, gebruik van diverse dataverzameling instrumenten:

a. Documentonderzoek waaronder de analyse van interne rapporten (bv. onderzoeksrapporten, specifieke adviesopdrachten), beleidsdocumenten (bv. sectorale beleidsplannen, projectgebonden beleidsplannen en opvolgingsrapporten) en verslagen (bv. beslissingen van het College en/of het managementteam);

b. Richtinggevende gesprekken met sleutelfiguren die het totale stadsbestuur overschouwen. Concreet kan hierbij gedacht worden aan de stadssecretaris, de burgemeester en andere ambtenaren of (ex)politieke beleidsverantwoordelijken die een zeer goed zicht hebben op de lange termijn evoluties binnen de eigen stad. Of het kan gaan om academische experten en bovenlokale ambtenaren die vanuit hun functie veelvuldige contacten onderhouden met de Vlaamse centrumsteden (bv. bovenlokaal gefinancierde initiatieven);

c. Diepte-interviews met ambtelijke en politieke sleutelfiguren die een bepaald facet van het stadsbestuur vertegenwoordigen (bv. sectoraal, hiërarchisch) Concreet kan gedacht worden aan directeurs, sectorhoofden, diensthoofden en schepenen;

d. Panel- of groepsgesprekken, ofwel eenzijdig samengesteld uit politieke o ambtelijke beleidsverantwoordelijken ofwel gecombineerd samengesteld.

19. VALLET, N., DE RYNCK, F., o.c., p. 17-18

454 | Res Publica $₹ 2006 / 4$
Hoewel het exacte aantal van stad tot stad verschilt, gaat het om zo'n 30 à 60 documenten, 2 à 5 richtinggevende gesprekken, ${ }^{20} 30$ à 40 diepte-interviews ${ }^{21}$ en 3 à 5 groepsgesprekken. De data over het politiek en ambtelijk leiderschap zijn afkomstig uit al deze informatiebronnen. Het aandeel van het documentonderzoek is echter beperkt.

Deels parallel met en deels na de dataverzameling greep de data-analyse plaats. Zoals de gefundeerde theoriebenadering suggereert, komt deze analyse neer op een graduele ordening en duiding van de verzamelde data. Hierbij maken onderzoekers gebruik van zelf geconstrueerde en relevant geachte categorieën en subcategorieën (bv. kenmerken en thema's). In een eerste fase hebben we op basis van de verzamelde data drie clusters of groepen van relevante contextfactoren geïdentificeerd, in het onderzoeksrapport centrale aandachtspunten genoemd. Deze opdeling impliceert een onderscheid tussen organisatiestructurele, omgevingsgerichte en beleidsvormende contextfactoren. In darop volgende fasen werden de ma's die we binnen elk aandachtspunt meenden te kunnen onderscheiden. In het kader van dit artikel is het niet relevant om uitvoerig stil te staan bij de concrete gevolgen van het fasegewijs analysewerk. Geïnteresseerden kunnen we steeds doorverwijzen naar het onderzoeksrapport en gepubliceerde artikels. ${ }^{22}$ Het is echter wel relevant om het politiek en ambtelijk leiderschap te positioneren binnen het geheel aan onderzoeks- en analyseresultaten. Concreet komt het politiek en ambtelijk leiderschap aan bod bij twee kenmerken van de organisatiestructurele contextfactor. Enerzijds betreft het de bespreking van de arbeids- en taakverdeling en anderzijds de coördinatie en afstemming. Daarnaast komt het politiek en ambtelijk leiderschap ook aan bod bij diverse kenmerken en themata van de beleidsvormende contextfactor. Concreet gaat het om de afbakening en begrenzing van de ambtelijke en politieke verantwoordelijkheden en bevoegdheden binnen de verschillende beleidsvormingsprocessen.

\section{De empirische inzichten in de lokale leiderschapstandem}

In wat volgt staan we achtereenvolgens stil bij de algemene kenmerken van he politiek en ambtelijk leiderschap zoals momenteel waargenomen door het CBS en de leden van het managementteam (zie A.), bij de meer concrete en specifieke kenmerken of finesses ervan (zie B en C), bij de implicaties voor de werking van

20. Duurtijd per interview: 1 à 2 uur.

21. Duurtijd per interview: 2 à 3 uu

22. O.a. VALLET, N., DE RYNCK, F., o.c.; VALLET, N., DE RYNCK, F., BLOCK, T., Kijken naa stadsorganisaties in Vlaanderen. Kansen, uitdagingen, grenzen en illusies omtrent het gebruik van de stadsmonitor voor leefbare en duurzame Vlaamse steden, Praktijkgids Management voor Lokale Besturen, 2005, p. 13-46. 
de lokale leiderschapstandem (zie D) en ten slotte bij de factoren die deze tandem beïnvloeden (zie E). Daar waar aangewezen wordt er expliciet verwezen naar het theoretische referentiekader. Op deze wijze worden de empirische bevindingen theoretisch verankerd.

\section{A. Enkele algemene kenmerken}

Via de lokale leiderschapstandem wijzen we het politiek en ambtelijk leiderschap toe aan de leden van het CBS en het managementteam. De onderzoeksresultaten tonen aan dat we bij deze wettelijk onderbouwde ${ }^{23}$ en "vanzelfsprekende" toewijzing toch enkele kanttekeningen moeten plaatsen.

Vooreerst wordt de centrale leiderschapsrol in de praktijk niet steeds formeel uitgewerkt of vorm gegeven. ${ }^{24}$ Over de formele uitwerking van het strategische leiderschap, d.w.z. de lange termijn en organisatieoverkoepelende aansturing, bestaat er bijvoorbeeld veel onduidelijkheid. Men gaat er vooral "van uit" dat dit soort van strategische aansturingrollen thuishoren bij de ambtelijke top én bij het CBS. Maar, in de praktijk wordt de concrete invulling van deze rollen sterk belemmerd door 2 factoren, namelijk een uitgesproken operationele i.p.v. strategische focus en een gebrekkige ondersteune king op het feit dat de politieke en ambteil rollen. Zoals ook nog later ter sprake zal komen in dit artikel (zie F) blijkt de agenda en de tijdsbesteding van het CBS en lokale topambtenaren immers sterk gedomineerd te worden door operationele zaken ("de druk van het operationele is een constante"). Het tweede heeft betrekking op het feit dat er op het vlak van respecialiseerde stafmedewerkers niet of slechts een zeer beperkte ondersteuning bestat voor strategische ansturingrollen. In het ambtelije apparat is het anta strategische stafmedewerkers toegevoegd aan de managementteams zeer beperkt en doorgaans afwezig. ${ }^{25}$ In het lokale politieke apparaat stelt zich een gelijksoortig probleem i.v.m. het aantal kabinetsmedewerkers. Zeker in vergelijking tot de andere bestuursniveaus zijn de kabinetten binnen stadsbesturen veel kleiner en zelfs afwezig.

Een tweede kanttekening heeft betrekking op het politiek leiderschap van he CBS. Op basis van de onderzoeksresultaten stellen we vast dat de intensiteit en

23. Zie o.a. Gemeentedecreet, 15 juli 2005, Titel II, Hfst. II, Afd. III: De bevoegdheden van het college van burgemeester en schepenen, artikel 57 en Hfst.V, Afd. II, Onderafd. IV: het managementteam, artikel 98 .

24. VALLET, N., \& DE RYNCK, F., o.c., p. 30-32

25. In de longitudinale gevalstudies kent enkel het stadsbestuur van Antwerpen 1 strategische coördinator die toegevoegd wordt aan de stadssecretaris en het Antwerpse managementteam. Via de focusgroep gesprekken stellen we vast dat dit in de overige centrumsteden eerder uitzondering dan regel is

456 | Res Publica $\$ 2006 / 4$ de wijze waarop het CBS in Vlaamse stadsbesturen aanstuurt zeer heterogeen en divers is. ${ }^{26}$ In dit opzicht heeft het politiek leiderschap vele gezichten, waarover zodadelijk meer (zie B)

Een derde algemene vaststelling heeft te maken met het ambtelijke leiderschap van het managementteam. Algemeen kunnen we stellen dat de desbetreffende aansturing doorgaans zwak en weinig voelbaar is. ${ }^{27}$ Managementteams slagen e moeilijk in om hun organisatieoverkoepelende en integrerende leiderschapsro op te nemen. Diverse redenen kunnen hiervoor worden aangehaald, waarover deze vaststelling niet impliceert dat er geen ambtenaren of ambtelijke diensten bestaan die een aanzienlijke aansturing binnen de integrale of belangrijke delen van de organisatie bewerkstelligen. Op basis van de onderzoeksresultaten stellen we bijvoorbeeld vast dat de aansturingrol van sommige diensthoofden (i.e. middenmanagers) het eigen beleidsdomein overstijgt en daardoor indirect ook andere, belendende delen van het stadsbestuur beïnvloeden. Concreet kan hierbij gedacht worden aan de voormalige coördinatoren van het Social Impulsfonds, de het ruimtelijk structuurplan en de coördinatoren van het Stedenfonds.

\section{B. Het veranderende en heterogene gezicht van het politiek leiderschap waar-} genomen door het CBS

Zoals hiervoor aangehaald, vertoont het politiek leiderschap van het CBS vele gezichten. Concreet kunnen we deze heterogeniteit typeren aan de hand van vijf inductief gegenereerde dimensies. Deze dimensies stellen ons in staat om de huidige situatie binnen Vlaamse stadsbesturen op een realiteitsgetrouwe en voor de stadsbesturen herkenbare wijze te typeren ${ }^{28}$ Anders gesteld, de dimensies maken het mogelijk om de gedragsmatig vertoonde leiderschapsstijl van het CBS op een realiteitsgetrouwe wijze te specificeren.

De invulling per stadsbestuur komt in dit artikel niet aan bod. Om dit te bewerkstelligen moeten de respectievelijke dimensies nog verder worden doorvertaald in een concreet meetinstrument en nauwgezette metingen in alle stadsbesturen. ${ }^{29}$ Dit is mogelijks het aandachtspunt van een vervolgonderzoek. Momenteel stellen de dimensies ons alvast in staat om de ontwikkelingen en evoluties binnen en tussen de onderzochte stadsbesturen op een onderling vergelijkende wijze te typeren. Ontwikkelingen kunnen zich voordoen m.b.t. één of meerdere dimensies:

26. VALLET, N., \& DE RYNCK, F., o.c., p. 88-89.

27. VALLET, N., \& DE RYNCK, F., o.c., p. $89-90$ en $31-32$

2. In het onderzoek hebben we vooral de situatie binnen de laatste twee legislaturen geanalyseerd.

Het onderzoek beperkt zich tot metingen in 4 stadsbesturen en discussies op focusgroep niveau omtrent de werkbaarheid van deze dimensies binnen de overige stadsbesturen. 
- Een stabiel versus een wisselend of veranderend leiderschap. We stellen vast dat het politiek leiderschap in verscheidene stadsbesturen sterk onderhevig is aan (tijdsgebonden) evoluties. Dit stellen we niet enkel vast op basis van he longitudinaal gevalstudie onderzoek binnen de steden Oostende, Antwerpen, Mechelen en Leuven, maar ook aan de hand van de verschillende focusgroep gesprekken ${ }^{30}$ Een stabiel politiek leiderschap impliceert eenzelfde, onveranderlijke of standvastige aansturing van het CBS (bv, gelijkblijvende accenten en prioriteiten). Een veranderend leiderschap daar en tegen impliceert veranderingen waardoor er (tijdelijk) meer onzekerheid, onduidelijkheid en minder transparantie kan bestaan (bv. wat zijn de accenten? wat is de koers?). Zo verwijzen respondenten in het onderzoek bijvoorbeeld naar snel op elkaar volgende "veranderingslawines" en het stilaan maar zeker "verliezen van de pedalen";

- Een sterk sturend versus een zwak sturend politiek leiderschap. De intensiteit of kracht van de aansturing verschilt eveneens. Een sterk sturend leiderschap impliceert volgens de onderzoeksresultaten dat de politieke beleidsverantwoordelijken het primaat van de politiek expliciet, krachtdadig en op een voor alle betrokkenen duidelijk zichtbare en waarneembare wijze opnemen. Een zwak politiek leiderschap daar en tegen impliceert dat het CBS als aanstuurder nauwelijks zichtbaar of voelbaar is ${ }^{31}$ Beide varianten alsook in de tijd evoluerende combinaties komen voor in de 4 onderzochte stadsbesturen. In het geval van een zwak politiek leiderschap spreken sommige respondenten ook wel eens over een "afwezig" politiek leiderschap;

Een eensgezind versus een sterk verdeeld politiek leiderschap. Deze dimensie heeft betrekking op de relaties tussen de leden van het CBS. In sommige stadsbesturen of op sommige momenten in de tijd, stellen we vast dat het CBS naar buiten treedt als één collegiaal sturend team vanuit eigen, gemeenschappelijk gedragen standpunten. In andere stadsbesturen is er duidelijk sprake van een voor de buitenwereld waarneembare verdeeldheid. De individuele profileringsdrang resulteert soms in openlijk waarneembare conflict- of "crisis" situaties. Concreet verwijzen respondenten hierbij naar publieke optredens in hoorzittingen of naar uitspraken die leden van het CBS doen in de pers;

30. In de marge van dit artikel kunnen we de bevindingen van een beleidsadviesrapport aanhalen dat het veterogene en evolutionaire karakter van het politieke leiderschap in de 13 Vla se centrumsteden bevestigt. Zo stelt het Rapport van de Vlaamse visitatiecommissie Stedenfonds eveneens dat het politiek leiderschap zeer diffuus en vooral sterk in verandering is. fonds eveneens dat het politiek leiderschap zeer diffuus en vooral sterk in verandering is.
Elke stad kent hierbij een eigen traject en ontwikkelingspatroon, aldus de auteurs van dit rapport. Zie DE RYNCK, F., TOPS, P., Leren van en over steden. Visitatie Stedenfonds, Brussel, port. Zie DE RYNCK, F., TOPS, P., Leren van en
Vlaamse Gemeenschap Stedenbeleid, 2005, p. 49-50.

31. Volgens het eerder vermelde Rapport van de Vlaamse visitatiecommissie Stedenfonds zou er binnen de Vlaamse steden in vergelijking tot de Nederlandse steden sprake zijn van een algemene "versterking" van het politiek leiderschap. In heel wat Vlaamse steden zijn "sterke" figuren politiek actief, d.w.z. politici die reeds heel wat ervaringen hebben opgebouwd in diverse beleidsfuncties. Deze lange en breedvoerige ervaring heeft zo zijn gevolgen voor de lokale politiek aansturing. Zie DE RYNCK, F., TOPS, P., o.c., p. 49-50.
- Een sterk gepersonaliseerd versus een onpersoonlijk, functioneel politiek leiderschap. In het eerste geval kan het politiek leiderschap worden teruggebracht tot de aanwezigheid van sterk persoonsgebonden capaciteiten of uitstraling. Het politiek leiderschap van een dergelijk stadsbestuur heeft op da ogenblik voor de buitenwereld letterlijk een duidelijk gezicht. In het tweede geval vloeit het politiek leiderschap voort uit de formele, institutioneel vastgeegrever ( dit nu eenmaal hoort bij hun takenpakket. In het onderzoek wordt er bijvoorbeeld verwezen naar het engagement, de "drive" en het enthousiasme waarmee politici hun mandaat opnemen;

- Een politiek leiderschap dat is ingebed in een sterk versus een zwak gepolitiseerd klimaat. We stellen vast dat de sturingsrol in sommige stadsbesturen sterk is ingebed in een uitgesproken, partijpolitieke en verzuilde context. Het CBS stuurt aan binnen CBS-overstijgende politieke verhoudingen en machtsconstellaties. Partijpolitieke tradities en de effecten van de coalitievorming werken voelbaar door. Respondenten verwoorden dit met "de gevoeligheid voor externe partijpolitieke druk". Het CBS overstijgt of verzacht zelden de partijpolitieke verdelingen. In andere stadsbesturen, of op andere momenten in de tijd, spelen partijpolitieke erfenissen en beleidscontouren veel minder een rol.

Naast deze inductieve dimensies is het eveneens zo dat, zeker voor de buitenwereld, de figuur van de burgemeester belangrijk is voor de perceptie m.b.t. het politiek leiderschap in en van stadsbesturen. Concreet stellen we vast dat de burgemeester vooral een cruciale rol speelt in de algemene aansturing van het college, de grote stadsprojecten en de strategische of lange termijn beslissingen. Op deelniveaus speelt het leiderschap van de schepenen echter eveneens een belangrijke rol. In elk stadsbestuur zijn er voorbeelden te geven van programma's, projecten en hervormingen in verschillende domeinen die vooral onder het leiderschap van en welbepalde schepen tot stand zijn gekomen. Kortom, het lijkt ons aangewezen om de sturende rol van de burgemeester voldoende situationeel te benaderen en deze rol bijvoorbeeld expliciet te positioneren t.o.v. andere schepenen. Het politiek leiderschap reduceren tot dat van de burgemeester is dus op basis van de onderzoeksresultaten zeker geen realiteitsgetrouwe zienswijze

Tot slot kunnen we onze onderzoeksresultaten theoretisch verankeren. Volgens de synthese van Edinger sluiten de onderzoeksresultaten zowel aan bij de descriptieve als bij de analytische traditie. ${ }^{32}$ De inductief geïdentificeerde dimensies liggen duidelijk in het verlengde van de stijlen geïdentificeerd binnen de descriptieve traditie (bv. de sterkte of intensiteit van het politiek leiderschap: zwak of tieve traditie (bv. de sterkte of intensiteit van het politiek leiderschap: Zwak of
sterk sturend). Maar, in tegenstelling tot de descriptieve traditie identificeren wij eerder dimensies of onderdelen van politieke leiderschapsstijl, plaatsen we deze dimensies als set bij elkaar en identificeren we eveneens dimensies die niet direct

32. EDINGER, L.J., o.c., p. 512-513 
centraal staan binnen de descriptieve traditie. Onze onderzoeksresultaten volgen eveneens de analytische traditie, waarover later meer bij de bespreking van de beïnvloedend factoren (zie IV F).

\section{Het wazige maar zoekende gezicht van het ambtelijk leiderschap waargeno-} men door het managementteam

Doorgaans kunnen we op basis van de onderzoeksresultaten stellen dat het ambtelijke leiderschap van het managementteam weinig voelbaar is en moeizaam verloopt.

Concreet blijkt dit vooreerst uit de overwegend interne beheersfocus. De meeste managementteams beperken hun aansturingrol tot het interne beheer van het managementteams beperken hun aansturingrol tot het interne beheer van het
stadsbestuur als organisatie. Inzake de externe profilering van het stadsbestuur in de stedelijke omgeving, zeg maar de externe beleidsfocus, sturen ze aanzienlijk minder of zelfs niet aan. ${ }^{33}$ Op deze wijze is de totale aansturing slechts fragmentair en zo weinig voelbaar.

Daarnaast verloopt de interne beheersrol d.w.z. de algehele coördinatie en afstemming binnen het integrale stadsbestuur erg moeizaam. ${ }^{34}$ Managementteams worden verondersteld om binnen hun leidinggevende rol vooral de integratie van de verschillende stadsdiensten, afdelingen en tijdelijke werkvormen (bv. stadsprojecten) aan te sturen. We stellen vast dat er binnen de meeste Vlaamse stadsbesturen wel formele aansturingarrangementen op topniveau bestaan - de stadsbesturen wel formele aansturingarrangementen op topniveau bestaan - de
managementteams krijgen stilaan maar zeker een formele invulling - maar tezelfdertijd blijven stadsbesturen worstelen met de feitelijke invulling en uitwerking van deze integrerende rol. Mogelijks is de idee van een ambtelijk managementteam daarvoor institutioneel nog te jong. ${ }^{35}$ De concrete structurele en personeelsmatige invulling van deze arangementen moet nog rijpen (bv. wat zijn de concrete taken en verantwoordelijkheden? Over welke competenties dienen de leden van het managementteam te beschikken? Wat is de positie t.a.v. het CBS?...).

Tegelijkertijd stellen we vast dat diverse Vlaamse stadsbesturen het ambtelijk leiderschap toch proberen te versterken ${ }^{36}$ Concreet gebeurt dit via de aanstelling van nieuwe functiebekleders (bv. in de functie van stadssecretaris, directeur en of afdelingshoofd), een uitbreiding van het aantal leden (bv. een vertegenwoordiging van alle stadsdiensten en -afdelingen), een verandering van de samenstelling van het managementteam (bv. een "verjongingskuur") en pogingen tot een

33. Een gelijksoortige vaststelling treffen we aan in het Rapport van de Vlaamse visitatiecommissie Stedenfonds, zie DE RYNCK, F., TOPS, P., o.c., p. 50 .

34. VALLET, N., \& DE RYNCK, F., o.c., p. 35-36.

35. Het managementteam als concept is verbonden aan het Nieuw Gemeentedecreet (15 juli

36. VALLEET, N., \& DE RYNCK, F., o.c., p. 90-91. meer actieve rol in de ingezette organisatieveranderingstrajecten en stadsprojecten. In dit opzicht is het gezicht van het ambtelijk leiderschap wazig, maar zeker zoekende in de richting van een meer expliciete en voelbare aansturing.

Tot slot kunnen we net zoals bij het politiek leiderschap, ook de hoedanigheid van het ambtelijke leiderschap typeren aan de hand van een drietal inductief gegenereerde dimensies. Deze dimensies stellen ons opnieuw in staat om de gedragsmatige leiderschapsstijl van het managementteam op een realiteitsgetrouwe Pstijl van het make Concreet betreft het de volgende dimensies ${ }^{37}$

Een intern versus extern gericht ambtelijk leiderschap. Zoals reeds aangehaald bij de bespreking en toelichting van de zwakke aansturing, zijn de meeste managementteams gericht op het intern aansturen van het stadsbestuur. Slechts een beperkt aantal houdt zich bezig met de externe profilering d.w.z. de rol en opdracht van het stadsbestuur ten aanzien van de stedelijke omgeving. Dit laatste impliceert een zeer uitgesproken, beleidsmatige i.p.v. beheersmatige rolinvulling;

- Een initiërend versus een volgend ambtelijk leiderschap. Deze dimensie speelt vooral een rol bij stadsbestuurlijke veranderingstrajecten. In het onderzoek stellen we bijvoorbeeld vast dat managementteams op bepaalde momenten kunnen opteren voor een zeer actieve en/of partnerachtige aansturing samen met het CBS. Dit impliceert concreet dat de leden van het managementteam eveneens initiatieven of voorstellen kunnen formuleren t.a.v. het CBS. Anderzijds kan er geopteerd worden voor een meer passieve rol. Het CBS krijgt dan het alleenrecht op het nemen van initiatieven en het managementteam zorgt het alleenrecht op het nemen van initiatieven en het managementteam zorgt
voornamelijk voor de uitvoerende aansturing. Stadsbesturen kunnen éénduidig kiezen voor het ene of het andere, maar kunnen ook opteren voor (tijdsgebonden) combinaties;

- Een sterk sturend versus zwak sturend ambtelijk leiderschap. Analoog met het politiek leiderschap gaat het hier om de intensiteit of kracht van de aansturing. Een sterk sturend ambtelijk leiderschap impliceert dat de leden van het managementteam hun aansturingrol expliciet, krachtdadig en op een voor alle betrokkenen duidelijk zichtbare en waarneembare wijze opnemen. Een zwak leiderschap daar en tegen impliceert dat deze aansturingrol nauwelijks zichtbaar of voelbaar is. Opnieuw zijn eenduidige of gecombineerde invullingen mogelijk

Analoog met de rol van de burgemeester kunnen we ons de vraag stellen in hoeverre de stadssecretaris een belangrijke rol speelt bij de algehele perceptie van het ambtelijk leiderschap. Op basis van de huidige onderzoeksresultaten hebben we hierop echter onvoldoende zicht. Additioneel onderzoek is hiervoor nodig.

Over de theoretische verankering kunnen we kort zijn. In principe bemoeilijkt het gebrek aan een heldere en uitgebreide theoretische typering een degelijke inbed-

37. VALLET, N., \& DE RYNCK, F., o.c., p. 89 
ding of positionering van onze onderzoeksresultaten. De vakliteratuur over politiek-ambtelijke verhoudingen laat alvast associaties en koppelingen toe (vb. een intern, volgend, zwak leiderschap bij een klassieke invulling van de politiekambtelijke verhoudingen), maar ze zijn beperkt en niet zuiver. De literatuur over de politiek-ambtelijke verhoudingen gaat immers over meer dan enkel over leiderschapsstijlen. Wat we inductief hebben gevonden vormt dan ook eerder een aanvulling op het bestaande theoretisch referentiekader.

\section{De totale leiderschapstandem... naar een vlotte sprint voorwaarts?}

Op basis van het voorgaande is het niet eenvoudig om de lokale leiderschapstandem in Vlaamse stadsbesturen te typeren. Vooral de heterogeniteit en de ontwikkelingen maken dat de leiderschapstandem sterk varieert en nog geen duidelijke of definitieve invulling heeft gekregen. In zover dat dit ooit een meer duidelijke en stabiele invulling kan krijgen - dat laten we voorlopig in het midden - lijkt het ons dan ook niet aangewezen om al te rigide en zo waarschijnlijk weinig realiteitsgetrouwe uitspraken te formuleren. Zoals gebruikelijk bij de gehanteerde methodologie (i.e. de gefundeerde theoriebenadering) verloopt elke theorieontwikkeling via trappen of opeenvolgende onderzoeken waarbij elke trap een verdieping impliceert van de voorgaande. Alle trappen samen resulteren op termijn in de ontwikkeling van een zogenaamde "grand" of allesomvattende theorie. Het huidige onderzoek heeft voornamelijk inzichten opgeleverd over de afzonderlijke bouwstenen van de leiderschapstandem - de aard en hoedanigheid van het politiek leiderschap enerziids en het ambtelijk leiderschap anderzijds (zie $A, B$ en $C$ )(zie E). De combinaties en ving of invulling van alle Vlaamse leiderschapstandems was nog niet aan de orde. Dit vergt additioneel en ook andersoortig onderzoek (bv. geen gevalstudie onderzoek maar beschrijvend breedteonderzoek dat betrekking heeft op alle 13 Vlaamse stadsbesturen)

Dit alles wil echter niet zeggen dat we helemaal geen tandemgerelateerde inzichten hebben bekomen. Niet tegenstaande de heterogeniteit en de aanwezige evoluties, hebben we alvast opgemerkt dat vooral de zoektocht vanwege het ambtelijk leiderschap zorgt voor de nodige spanningen binnen de leiderschapstandem. Van een vlotte sprint voorwaarts is er dan ook niet altijd sprake.

In zover het politiek leiderschap in een complementariteit gelooft, of een gelijkwaardige aansturing accepteert, of een sterk ambtelijk leiderschap zelfs prefereert omdat het een welgekomen remedie is voor eigen zwaktes (i.e. indien er bijvoorhoegenaamd geen probleem rond dit zoekend ambtelijk leiderschap. In dit geval ontwikkelen zich vreedzame coëxistenties of synergetische formules binnen de leiderschapstan$\mathrm{dem}$. Spanningen ontstaan echter van zodra er krachten bestaan die de ambtelijke zoektocht tegenwerken of die maken dat het politiek leiderschap niet gelooft in een vreedzame coëxistentie, een gelijkwaardige aansturing of complementariteit.

462 | Res Publica $\vee 2006 / 4$
Dit impliceert dat het zoekend ambtelijk leiderschap in aanvaring komt met het politiek leiderschap.

\section{E. Factoren die de lokale leiderschapstandem beïnvloeden}

Aan de hand van de onderzoeksresultaten stellen we vast dat diverse factoren een invloed kunnen uitoefenen op het politiek en ambtelijk leiderschap. Ze bepalen eveneens waarom er eventuele spanningen ontstaan binnen de lokale leiderschapstandem. Sommige factoren maken deel uit van de externe omgeving van stadsbesturen, andere factoren hebben betrekking op de typische kenmerken van het stadsbestuur zelf en nog andere factoren bevinden zich deels buiten en deels binnen het stadsbestuur.

Figuur 1 geeft een overzicht van de in het onderzoek aangetroffen invloeden. De volle lijnen stellen de directe invloeden voor en de stippellijnen de indirecte verbanden. Volledigheidshalve moeten we opmerken dat de invloeden als gevolg van de gehanteerde onderzoeksmethode de status hebben van inductieve hypothesen of op empirie gebaseerde vermoedens. Zoals het past binnen de gefundeerde theoriebenadering volgen falsificaties na de constructie van theoretische

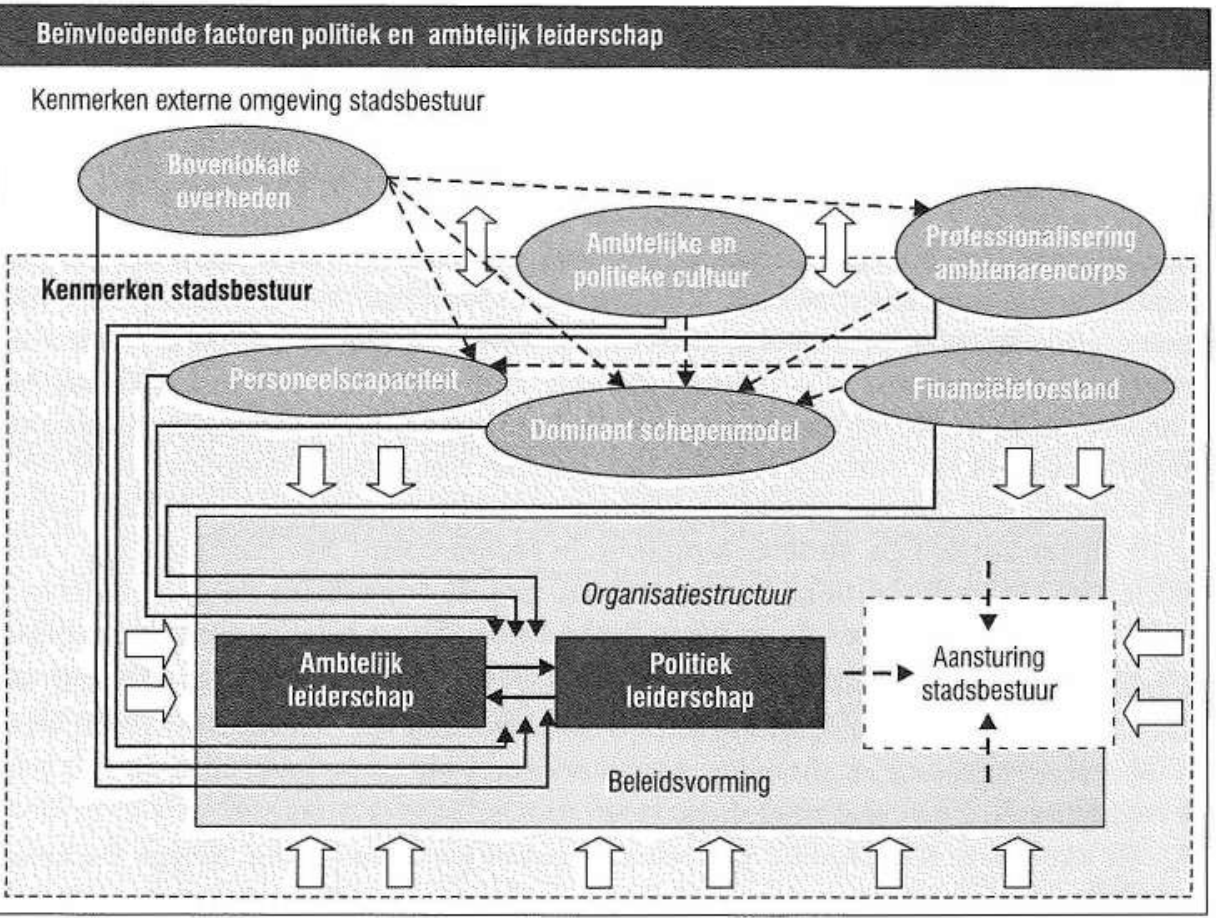

Figuur 1. Invloeden op de lokale leiderschapstandem. 
modellen. Aangezien deze theoretische modellen echter gebaseerd zijn op empirische data en waarnemingen, is het realiteitsgetrouwe karakter van de hierin vervatte hypothesen vermoedelijk groot.

Een eerste kenmerk van Vlaamse stadsbesturen is de dominante invloed vanwege het zogenaamde schepenmodel. ${ }^{38}$ In de literatuur over lokale besturen is er vaak sprake van twe bestuurskundige modellen: het zogenaamde schepenmodel en het zogenaamde diensthoofdenmodel ${ }^{39}$, de benaming die voor het ambtelijke topoverleg wordt gebruikt in het nieuwe gemeentedecreet. ${ }^{40}$

Volgens het schepenmodel is de verdeling van bevoegdheden tussen politieke partijen en schepenen zeer determinerend voor de werking van stadsbesturen. Per beleidsdomein of pakket van politieke bevoegdheden organiseert elke schepen zich met 'zijn' of 'haar' diensten. Op het niveau van de hele organisatie zien we dan een structuur ontstaan die steunt op een politieke verdeling of verkaveling. Bij het managementteam model is er eerder sprake van een beperkt collectief van topambtenaren dat in onderlinge dialoog treedt en als collectief onderhandelt met het CBS. Het CBS formuleert op basis van een beleidsvoorbereidende voorzet van het managementteam, de krachtlijnen van het beleid. Deze worden vervolgens onder de leiding van het managementteam uitgevoerd. Bij het managementteam model horen welbepaalde beleidsinstrumenten. Concreet gaat het over afsprakennota's tussen het CBS en het managementteam en de verplichte opmaak van een hele reeks strategische beleidsdocumenten. Deze documenten worden eerst binnen het managementteam besproken en vervolgens als advies overgemaakt aan het CBS. Dit alles illustreert dat het managementteam model bedoe is om te breken met de tradities van het politiek verkokerde schepenmodel.

Op basis van de onderzoeksresultaten stellen we vast dat het schepenmodel momenteel sterk domineert binnen Vlaamse stadsbesturen. We kunnen echter niet van een zuiver schepenmodel spreken maar wel over een in de tijd getemperd en gemengd schepenmodel. Zo melden diverse respondenten bijvoorbeeld dat het Zordt getemperd door het a burgemeester of het bestaan van een kernkabinet dat andere schepenen overvleugelt zodanig dat niet het voltallige CBS maar slechts een beperkt deel kan wegen op de organisatie. Een andere, temperende factor vormt het partijpolitiek vooroverleg en de partijpolitieke bijeenkomsten met de fracties uit de gemeenteraad. In dit geval geven eerder de partijpolitieke belangen en relaties i.p.v. de schepenen gestalte aan het schepenmodel. En ten slotte is er ook sprake van een ge-

mengd schepenmodel. Her en der stellen we immers vast dat er bescheiden stap-

38. VALLET, N, \& DE RYNCK, F, O.c., p. 25-27,

39. DE RYNCK, F., BOUCKAERT, G., Praktisch Handboek voor Gemeentebeleid, Brugge, Die Keure,

40. Zie o.a. Gemeentedecreet, 15 juli 2005, Titel II, Hfst. V, Afd. II, Onderafd. IV: het managementteam, artikel 98

464 | Res Publica $\vee 2006 / 4$ pen worden ondernomen in de richting van een gestructureerd overleg op topmanagement niveau. Hierdoor krijgt het managementteam model langzaam aan gestalte naast het schepenmodel.

Ingevolge het dominant aanwezige schepenmodel - zelfs onder zijn getemperde vorm - wordt vooral het politiek leiderschap structureel ondersteund in de lokale leiderschapstandem. De politieke verkokering van de organisatiestructuur zorgt immers voor een vrij directe en ambtelijk ongestoorde uitoefening van het politieke leiderschap. Mogelijks vormt de ontwikkeling op termijn van een gemengd model de basis voor een meer evenwichtige en harmonieuze leiderschapstandem, maar momenteel vinden we hiervan nog geen voorbeelden. Dit tijdelijke onevenwicht zorgt mogelijks voor de vastgestelde spanningen (zie D).

De lokale leiderschapstandem wordt eveneens beïnvloed door de toenemende druk op de bestaande personeelscapaciteit die zich vooral laat voelen in het integrale ambtenarencorps ${ }^{41}$ We stellen vast dat de meeste Vlaamse stadsbesturen doorgaans veel tijd, aandacht en energie besteden aan het operationele beleid d.w.z de concrete realisatie van korte termijn acties en directe, beleidsdomein gekoppelde dienstverlening. Dit stellen we niet enkel vast bij het operationele ambtenarencorps, maar evengoed bij het midden- en topkader. De dagdagelijkse, reguliere werking eist zeer veel aandacht op, zeker gegeven de steeds meer gehoorde credo's van klantgerichtheid, kwaliteitsvolle dienstverlening en verantwoordelijkheid of aansprakelijkheid. Hierdoor wordt er bijvoorbeeld veel aandacht opgeëist door interne veranderingstrajecten, diverse vormen en soorten van projectmanagement en bovenlokaal opgelegde planningsvereisten (zie ook verder). Dit alles resulteert volgens diverse respondenten in een toenemende druk op het ambtenarencorps. Niet enkel in kwantiteit aangezien de vragen meer dan evenredig toenemen t.o.v. de trage en soms constant gehouden omvang van het ambtenarencorps, maar ook in kwaliteit. De vereisten inzake strategische planningscapaciteiten bijvoorbeeld overtreffen het aanwezige aanbod ter zake. Bovendien verhindert de operationele druk een snelle inhaalbeweging. Opleidingen vereisen de nodige tijd.

We stellen vast dat deze capaciteitsproblematiek tot gevolg heeft dat het managementteam zelden tijd en ruimte vindt om haar ambtelijk leiderschap op een actieve, intense en systematische wijze op te nemen. Dit zorgt opnieuw voor de nodige onevenwichten en additionele spanningen binnen de lokale leiderschapstange one
dem.

De financiële situatie interageert met de operationele druk en de hiervoor geschetste capaciteitsproblematiek Op basis van de onderzoeksresultaten stellen we immers vast dat de schuldenlast en de hiermee gepaard gaande besparingsrondes de inhoud en vooral de grenzen bepalen van het lange termijnbeleid. ${ }^{42}$ In functie van de

41. VALLET, N., \& DE RYNCK, F., o.c., p. 94-95 en p. 99-100.

42. VALLET, N., \& DE RYNCK, F., o.c., p. 101-102. 
financiële ruimte worden geplande lange termijn intenties herzien en desnoods geschrapt in het voordeel van korte, ad hoc-achtige acties. Dit vergroot de operationele druk, zeker indien dit gepaard gaat met additionele personeelsbesparingen. De financiële toestand heeft dan ook vaak een versnellings- of accumulatie-effect. Bovendien wordt de besparingsgerichte begrotingscyclus doorgaans geïnitieerd en zo ook aangestuurd door het CBS die hierdoor het dominante schepenmodel en het politiek leiderschap binnen de lokale leiderschapstandem activeert of versterkt.

Een vierde invloed gaat uit van de zogenaamde professionaliseringstrend binnen het lokale ambtenarencorps. ${ }^{43}$ Deze trend situeert zich deels binnen de stadsbewe immers eveneens aan op andere, bovenlokale bestuursniveau's (bv. Vlaams, federaal, Europees). Onder ambtelijk professionalisme verstaan we de aanwezigheid van die kennis, kunde en vaardigheden die nodig zijn om een kwaliteitsvolle, beleidsondersteunende rol te vervullen. Enerzijds betreft het de aanwezigheid van een vaktechnische expertise, anderzijds van een managementmatige expertise (bv, plannen, organiseren, leiding geven en controleren). Daar waar de voor( gaande factoren doorgaans leiden tot een vizwakking van het a milink leiderschap, leidt deze factor eerder tot een versterking hoewel de vaststellingen niet zo
eenduidig zijn dan mogelijks deductief verondersteld.

Niettegenstaande we verschillen vaststellen tussen de bestudeerde stadsbesturen zien we bijvoorbeeld dat het ambtelijke professionalisme over het algemeen beperkt aanwezig is, zeker op het vlak van managementcapaciteiten. Er doen zich voorzichtige inhaalbewegingen voor, maar deze zijn doorgaans beperkt. Stadsbe sturen werven nog steeds in de eerste plaats vaktechnici aan waarvan ze mogelijks veronderstellen dat deze ook automatisch managementcapaciteiten hebben inzake, planning organiseren en leiding geven. Leden van het managementtean vormen geen uitzondenter. Het lidvor maatschap van het managementteam is vaak gestoeld op een vaktechnische, anciënniteitgebonden klim binnen in de organisatie. Dit overwegend vaktechnisch professionalisme remt echter de laterale coördinatie en het lateraal aansturen af. Dit gebeurt ten voordele van een verkokerde vaktechnische leiderschapstijl die zo trouwens goed aansluit bij het dominante schepenmodel en een sterk politiek leiderschap. In dit opzicht is het ambtelijke professionalisme zeker (nog) niet van dien a l om stadsbeturen mer vanuit een generalistische en laterale visie aan te sturen, of dus het ambtelijk leiderschap kracht bij te zetten.

Maar, er is ook een tweede tendens voelbaar binnen de professionalisering van het a leidt tot een versterhet a king van het ambtelijk leiderschap, maar tegelijkertijd ook voor de nodige spanningen kan zorgen binnen de lokale leiderschapstandem. Zo stellen we vast dat er binnen de bestudeerde stadsbesturen sprake is van een duidelijk toegenomen instroom van nieuwe professionelen die zich zeer expliciet wensen te profileren,

43. VALLET, N., \& DE RYNCK, F., o.c., p. 49-51, 91-92 en 103-104 niet enkel binnen het eigen maar ook in belendende of aanverwante beleidsdomeinen. Over het algemeen en zonder nuancering per stad, lijkt deze kwantitatieve instroom van naar profilering zoekende ambtenaren een gunstige invloed te hebben op het versterken van het ambtelijke leiderschap. Dit is zeker het geval indien deze op termijn deel zullen uitmaken van het managementteam en indien de sterkingsoperaties bij B). Tezelfdertijd lijkt er echter een druk aanwezig te zijn en volgens sommigen ook toe te nemen, waarbij politieke beleidsverantwoordelijken zich vooral willen profileren in de sfeer van de beleidsvoorbereiding en -uitvoering, om zo hun zichtbaarheid bij de burgers te verhogen. Een dergelijke expliciete profileringdrang zou volgens enkele respondenten passen bij de wens om de zogenaamde kloof met de burger te dichten. In de beide fasen van de beleidsvorming zou de spanning tussen het politieke en geprofessionaliseerde ambilike 作 deel van de lokale leiderschapstandem dan ook kunnen toenemen. Allebei wensen ze achter het stuur van de tandem plaats te nemen, zowel bij de start als de finish.

In het verlengde van het voorgaande is er vervolgens de invloed vanwege de ambtelijke en politieke cultuur. Hoewel we op basis van de onderzoeksresultaten vaststellen dat de politieke en ambtelijke cultuur een vrij complex en moeilijk te duiden concept is ${ }^{44}$ kunnen we doorgaans wel een onderscheid maken tussen een meer traditionele variant en een meer (ver)nieuw(d)e variant. Los van de complexe wijze waarop beide cultuurvarianten zich manifesteren, kunnen we stellen dat elke cultuurvariant een beduidend andere zienswijze hanteert ta.v. de rol die ambtelijke en een traditioneel ambtelijke cultuur bijvoorbeeld veel minder gericht op de organisatie als geheel of op de beleidsvoorbereiding, en veel meer op de eigen functie en vakexpertise, op een duidelijk hiërarchische positionering ten opzichte van "hogeren" en vooral de "politieke chefs" (i.e. het CBS), en op bureaucratische aspecten, kaders en grenzen van de eigen roluitoefening. In dit opzicht leidt een traditioneel ambtelijke cultuur volgens ons eerder tot een versterking van het schepenors duidelijk ondergeschikt aan het politiek leiderschap en manifesteert zich voornamelijk op het uitvoerende niveau binnen de grenzen van vaktechnische beleidskokers. Een (ver)nieuw(d)e ambtelijke cultuur vormt grotendeels de antipode van de traditionele cultuurvariant en pleit daardoor voor een meer gelijkwaardige rolinvulling van de lokale leiderschapstandem. De traditioneel politieke cultuur hanteert een complementair en zo versterkend waardenkader t.a.v. de gelijknamige ambtelijke individuele bewegingsvrijheid waardoor politieke beleidsverantwoordelijken in

44. We stellen in het onderzoek bijvoorbeeld vast dat bestaande theorieën en modellen over de politiek-ambtelijke verhoudingen niet echt bruikbaar zijn om de complexe realiteit van politiek en ambtelijke culturen binnen stadsbesturen te vatten. Zie o.a. VALLET, N., \& DE RYNCK, F., o.c., p. $128-133$ 
functie van electorale noden en opportuniteiten ad hoc en voor de burger op een zichtbare wijze kunnen handelen. De rolopvattingen over ambtenaren, inclusief de ambtelijke top zijn beperkt en klassiek: het primaat van de politiek stuurt de organisatie aan en het ambtelijk leiderschap wordt aanzien als een operationeel beleidsinstrument ter ondersteuning van de eigen, dominante leiderschapsrol.

Hoewel het onderzoek geen uitspraken doet over de mate - veel of weinig waarin de verschillende cultuurvarianten aanwezig zijn in de 13 Vlaamse centrumsteden, kunnen we wel uitspraken doen over de mogelijke gevolgen voor de lokale leiderschapstandem en vooral voor het eventueel ontstaan van spanninlijk ondergeschikt aan het politieke leiderschap. De leiderschaptandem is niet in evenwicht, maar er zijn geen noemenswaardige spanningen aangezien de traditionele ambtelijke cultuur de dominantie van politieke beleidsverantwoordelijken volledig aanvaardt. Spanningen ontstaan volgens ons van zodra traditionele en (ver)nieuw(d)e cultuurvarianten worden gecombineerd. De rolinvullingen zijn dan immers tegengesteld, wat leidt tot een onevenwichtige leiderschapstandem waarvan de plats a hter het stuur wordt betwist. Een evenwichtige en spanningsloze tandem treffen we tot slot aan wanneer de (ver)nieuw(d)e cultuurvari-
anten worden gecombineerd.

Een laatste invloed die we op basis van onze onderzoeksresultaten hebben kunnen identificeren is deze vanuit de bovenlokale overheden of bestuursniveaus ${ }^{45} \mathrm{Op}$ basis van de onderzoeksresultaten stellen we vast dat bovenlokale overheden (van provincie tot Europa) een grote invloed uitoefenen op de wijze waarop stadsbesturen zichzelf organiseren en aansturen. Concreet gebeurt dit bijvoorbeeld via opgelegde regelgeving (bv. het nieuwe gemeentedecreet), planningsvereisten (bv. lokale cultuurbeleidsplannen, mobiliteitsconvenanten, ruimtelijke tructur fonds). Soms impliceren deze bovenlokale invloeden beleidsdomeinoverschrijdende coördinatiearrangementen onder de vorm van lokale stuurgroepen, projectgroepen of commissies. Indien dergelijke coördinatiearrangementen een actieve participatie en aansturing vereisen vanuit de ambtelijke top, dan versterken bovenlokale overheden het ambtelijk leiderschap binnen de lokale leiderschapstandem. Tegelijkertijd stellen we echter vast dat sommige invloeden het ambtelijk opgelegde regelgeving en planningsvereisten vaak sectoraal zijn waardoor eerder de verticale relaties met de bovenlokale overheden worden geactiveerd, in plaats van de laterale relaties tussen de verschillende stadsdiensten binnen het eigen stadsbestuur. Op deze wijze versterken bovenlokale overheden het verkokerd denken van het schepenmodel, en zo ook de basis van het politiek leiderschap.

Bovenlokale overheden oefenen daarnaast ook bijkomende, eerder indirecte invloeden uit op de lokale leiderschapsbalans. Aan de hand van de onderzoeksre-

45. VALLET, N., \& DE RYNCK, F., o.c., p. $48-49$ en 101. sultaten stellen we vast dat de opgelegde planningsvereisten de eerder vermelde personeelscapaciteit, de financiële ademruimte en de professionalisering binnen het lokale ambtenarencorps beïnvloeden. De opmaak en implementatie van bovenlokale plannen vereist immers de nodige tijdsinvestering, budgettaire ruimte en professionele capaciteitsontwikkeling. Op deze wijze beïnvloeden de bovenlokale overheden eveneens indirect de verhoudingen binnen de lokale leiderschapstandem in het voordeel van een sterk politiek leiderschap.

Tot slot is er nog de theoretische verankering. Door de expliciete aandacht voor beïnvloedende factoren sluit ons onderzoek duidelijk aan bij de analytische traditie, meer bepaald bij de eerste of contextuele substroming. De door ons geïdentificeerde factoren die de leiderschapstandem beïnvloeden zijn immers uitgesproken ceerde factoren die de leiderschapstandem beïnvloeden zijn immers uitgesproken
contextuele factoren. De invloed van het dominante schepenmodel, de personeelscapaciteit, de financiële toestand en de professionalisering van het ambtenarencorps zijn organisatiestructurele factoren. De invloed vanwege de ambtelijke en politieke cultuur zijn daar en tegen culturele factoren. En de invloed vanwege de bovenlokale overheden is ten slotte een uitgesproken institutionele factor. Inren aan bod komen in ander onderzoek kunnen we stellen dat dit omwille van het zeer diffuse karakter van de desbetreffende literatuur een zeer moeilijke opdracht is. Op het eerste gezicht is de herkenbaarheid het grootst voor de financiële situatie, ${ }^{46}$ de personeelscapaciteit en de invloed van bovenlokale overheden. ${ }^{47}$ Ten slotte is het interessant om op te merken dat wij in tegenstelling tot de contextuele traditie niet zozeer de impact van al deze factoren op enkel het politiek leiderschap in kaart brengen, mar wel op de integrale lokale leidersch pandem. In dit opzicht voegt ons onderze tandem. In dit opzicht voegt ons onderzoek een contextuele factor toe aan de ana-
lytische traditie: het politiek leiderschap "in relatie tot" het ambtelijk leiderschap.

\section{Conclusie}

Het artikel rapporteert over enkele inductief verkregen inzichten in het politiek en ambtelijk leiderschap binnen Vlaamse stadsbesturen.

46. Hambleton verwijst naar de studies van Bullock (1993) en Schmoke (1993) waarin de aanwezigheid en het zoeken van financiële bronnen een belangrijke impact zou hebben op het lokaal leiderschap, HAMBLETON, R., o.c., p. 46

47. In zijn onderzoek stelt Martin vast dat bovenlokaal opgelegde maatregelen een grote druk op lokale besturen en hun personeelscapaciteit en -competenties uitoefenen.MARTIN, o.c., p. 27 -
29; In hun onderzoek stellen Borraz en John vast dat direct verkon burgemeeters soms 29; In hun onderzoek stellen Borraz en John vast dat direct verkozen burgemeesters soms kale middelen leides $\mathrm{k}$. o.c., p. 115. 
De onderzoeksresultaten stellen ons vooreerst in staat om beide leiderschapstijlen op een voor op een voor het onderzoeksveld herkenbare en relevante wijze creet kunnen we bij de politieke leiderschapsstijl waargenomen door het CBS gebruik maken van een vijftal dimensies, namelijk een stabiel versus veranderend leiderschap, een sterk sturend versus een zwak sturend politiek leiderschap, een eensgezind versus een sterk verdeeld politiek leiderschap, een sterk gepersonaliseerd versus een onpersoonlijk, functioneel politiek leiderschap en een politiek leiderschap dat ingebed is in een sterk versus zwak gepolitiseerd klimaat. Het ambtelijk leiderschap waargenomen door het managementteam kunnen we typeren aan de hand van een drietal dimensies, namelijk intern beheersmatig vers
extern beleidsmatig, initiërend versus volgend en sterk versus zwak sturend.

Daarnaast stellen we vast dat het politiek leiderschap een zeer heterogene invulling kent en momenteel volop in verandering is. Het ambtelijk leiderschap daarentegen is veel minder voelbaar maar wel zoekende. Beide aansturingen samen resulteren in een wat wij zelf de lokale leiderschapstandem noemen. Voor zover we momenteel kunnen inschatten bestaat er een reële de kans op aanzienlijke spanningen binnen de leiderschapstandem. Diverse factoren beïnvloeden dit spanningsveld. Op basis van de onderzoeksresultaten wordt dit beïnvloed door het dominante schepenmodel, de personeelscapaciteit, de financiële toestand, de ambtelijke en politieke cultuur, de professionaliseringstrend van het ambtenarencorps en bovenlokale overheden.

Wanneer we de inductieve onderzoeksresultaten ex post inbedden in de bestaande vakliteratuur, dan stellen we vast dat dit geen eenvoudige opdracht is. Het feit dat er diverse conceptuele invullingen bestaan en dat diverse vakgebieden zich buigen over het leiderschapsverschijnsel bemoeilijkt een heldere en ondubbelzinnige inbedding. Niettemin komen we tot de vaststelling dat we m.b.t. tot het politiek leiderschap vrij goed aansluiten bij zowel de descriptieve als de analytische traditie. Onze bevindingen vormen alvast interessante aanvullingen op het bestaande kenniscorpus. In verband met het ambtelijk leiderschap en zeker met betrekking tot de leiderschapstandem is er geen theoretische traditie. In dit opzicht leiden de inductieve onderzoeksresultaten naar nieuwe inzichten en een mogelijks in de toekomst verder te bewandelen onderzoekspad.

Ten slotte wensen we vanuit het onduidelijk conceptueel kader en het diffuse karakter van de vakliteratuur, ook de nood aan een meer geïntegreerde en interdisciplinaire benadering van de lokale leiderschapsproblematiek aan te kaarten. Zeker indien we het pad van de lokale leiderschapstandem verder wensen te bewandelen, is het belangrijk om te kunnen vertrekken vanuit een helder, overzichtelijk en voor de verschillende disciplines herkenbaar onderzoekskader. Concreet denken we aan een kruisbestuiving tussen de vakgebieden politicologie, bestuurskunde en management.
The local leadership tandem: an explorative research into the characteristics of political and civil servant leadership in Flemish cities

This article is based on a definition of political and civil servant leadership as a behavioral steering style towards the realization of organizational goals. By means of a grounded the ory methodology we get some insights in the characteristics and the interaction between both leadership styles in Flemish cities. This two-faced leadership is depicted by means of a tandem metaphor. First, we identify the relevant dimensions to describe the leadership tandem. It becomes apparent that political leadership styles differ greaty both in time and in scope. Civil servant leadership is generally characterized by a weak but presumably growing impact. This combination results in considerable leadership tensions, which is reinforced by several contingency factors: i.e. the influence of the dominant alderman model, the financial situation, the number of staff, the tendency to professionalize, the dominant political and civil servant culture and the structure of central government (e.g. on a Flemish, Belgian and European level. 